\title{
Spatiotemporal characterization of dissolved carbon for inland waters in semi-humid/semi-arid region, China
}

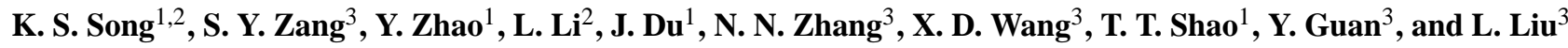 \\ ${ }^{1}$ Northeast Institute of Geography and Agroecology, CAS, Changchun, China \\ ${ }^{2}$ Department of Earth Sciences, Indiana University - Purdue University, Indianapolis, IN, USA \\ ${ }^{3}$ College of Geographical Science, Harbin Normal University, Harbin, China
}

Correspondence to: K. S. Song (songks@neigae.ac.cn, zsy6311@163.com)

Received: 24 April 2013 - Published in Hydrol. Earth Syst. Sci. Discuss.: 27 May 2013

Revised: 25 September 2013 - Accepted: 26 September 2013 - Published: 30 October 2013

\begin{abstract}
Spatiotemporal variations of dissolved organic carbon (DOC) and inorganic carbon (DIC) in 26 waters across the semi-humid/semi-arid Songnen Plain, China, were examined with data collected during 2008-2011. Fresh $(n=$ $14)$ and brackish $(n=12)$ waters were grouped according to electrical conductivity (threshold $=1000 \mu \mathrm{S} \mathrm{cm}^{-1}$ ). Significant differences in the average DOC and DIC concentrations were observed between the fresh $\left(5.63 \mathrm{mg} \mathrm{L}^{-1}\right.$, $\left.37.39 \mathrm{mg} \mathrm{L}^{-1}\right)$ and the brackish waters $\left(15.33 \mathrm{mg} \mathrm{L}^{-1}\right.$, $\left.142.93 \mathrm{mg} \mathrm{L}^{-1}\right)$. Colored dissolved organic matter (CDOM) and DOC concentrations were mainly controlled by climatic-hydrologic conditions. The investigation indicated that the outflow conditions in the semi-arid region had condensed effects on the dissolved carbon, resulting in close relationships between salinity vs. DOC $\left(R^{2}=0.66\right)$, and salinity vs. DIC $\left(R^{2}=0.94\right)$. An independent data set collected in May 2012 also confirmed this finding (DOC: $R^{2}=0.79$, DIC: $R^{2}=0.91$ ), highlighting the potential of quantifying DOC and DIC via salinity measurements for waters dispersed in the plain. Indices based on the CDOM absorption spectra (e.g., the DOC-specific CDOM absorption $\left(\mathrm{SUVA}_{254}\right)$, absorption ratio $a_{250}: a_{365}\left(E_{250}: E_{365}\right)$ and the spectral slope ratio ( $\left.\mathrm{Sr}, S_{275-295} / S_{350-400}\right)$ ) were applied to characterize CDOM composition and quality. Our results indicate that high molecular weight CDOM fractions are more abundant in the fresh waters than the brackish waters.
\end{abstract}

\section{Introduction}

Dissolved organic matter (DOM) is one of the largest bioactive reservoirs on the earth's surface (Cole et al., 2007; Para et al., 2010). Though covering only a small fraction of the earth's surface, inland waters have a disproportional effect on the global carbon cycle (Cole et al., 1994, 2007; Tranvik et al., 2009; Armstrong, 2010), and play a vital role in burying, cycling and emitting carbon (Cole et al., 1994, 2007; Downing et al., 2008). DOM of inland waters, particularly its colored fraction (CDOM), influences light attenuation in waters (Vodacek et al., 1997; Zhang et al., 2007; Williamson and Rose, 2010; Stedmon et al., 2011), which in turn affects the transport and bio-availability of materials such as trace metals and organic pollutants (Cory et al., 2006; Schlesinger et al., 2011; Ledesma et al., 2012). The mineralization of dissolved organic carbon (DOC), the major component of DOM, is a source of $\mathrm{CO}_{2}$ in the atmosphere (Cole et al., 2007; Duarte et al., 2008; Spencer et al., 2009; Tranvik et al., 2009). DOC also serves to mediate the chemical environment through organic acids (Wetzel, 2001; Tranvik et al., 2009) and to enhance or alleviate the toxic forms of heavy metals (e.g., aluminum or mercury) (Cory et al., 2006; Henneberry et al., 2011).

DOC mass balances are subject to the influences of temperature and precipitation, which can have important effects on DOC source, transport and fate (Larson et al., 2007; Jaffé et al., 2008; Fellman et al., 2011). Studies have indicated that concentrations of DOC in inland waters tend to decrease with increasing water residence times due to increased photobleaching and microbial activities (Curtis and Adams, 1995; 
Helms et al., 2008; Julian et al., 2008, 2011; Stedmon et al., 2011). Several investigations have also illustrated that CDOM is inversely associated with salinity in estuarine and nearshore waters due to dominating riverine DOC inputs (Vodacek et al., 1997; Twardowski et al., 2004; Griffin et al., 2011). Inland waters in semi-arid to arid climates, however, generally tend to exhibit high salinity concentrations with elevated DOC concentrations (Brooks and Lemon, 2007). Curtis and Adams (1995) reported a positive correlation between DOC and specific conductivity in semi-arid eastcentral Alberta, Canada. However, this phenomenon, caused by evaporative concentration, has not been thoroughly investigated in other places (Wetzel, 2001; Brooks and Lemon, 2007). The role of saline water in DOC cycling needs further investigation (Duarte et al., 2008).

The source and composition of DOM can be investigated using various analytical approaches (Summers et al., 1987; Baker and Spencer, 2004; Spencer et al., 2008). These methods primarily dependent on the ultraviolet-visible (UV-Vis) and fluorescence measurements have been widely applied and reported (Chin et al., 1994; Vodacek et al., 1997; Helms et al., 2008; Zhang et al., 2007, 2010; Fellman et al., 2011; Stedmon et al., 2011). Using the ratio of the absorptions

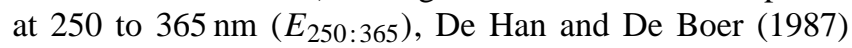
successfully tracked changes in DOM molecule size, which was confirmed by other researchers (Peuravouri and Pihlaja, 1997; Zhang et al., 2007). The spectral slope $(S)$ provides further information on the CDOM origin chemical processes and diagenesis, and the application of $S$ is not limited by CDOM concentration (Twardowski et al., 2004; Helms et al., 2008; Fichot and Benner, 2011). Recently, Helms et al. (2008) developed another index based on the ratio of $S$ value $(\mathrm{Sr})$ at two narrow wavelength ranges: the $S$ of the shorter wavelength region $(275-295 \mathrm{~nm})$ versus the longer wavelength region $(350-400 \mathrm{~nm})$. The effectiveness of $\mathrm{Sr}$ has been demonstrated with CDOM samples from various waters, ranging from DOC-rich wetlands to photobleached coastal waters and lakes over high-altitude plateaus (Helms et al., 2008; Zhang et al., 2010). Further, it has been modified to estimate DOC concentration using the CDOM absorption feature (Fichot and Benner, 2011; Spencer et al., 2012).

Dissolved inorganic carbon (DIC), largely composed of dissolved carbon dioxide and bicarbonate, is the primary source of carbon for photosynthesis and the generation of organic substances (Duarte et al., 2008). These inorganic compounds are generated by phytoplankton and higher plants in both lakes and rivers (Wetzel, 2001; Wilson and Xenopoulos, 2009), or they are generated externally in the drainage basin and imported to water bodies (Tranvik et al., 2009). The photobleaching process also produces DIC (Wetzel, 2001; Barros et al., 2011; Lapierre and Giogio, 2012). DIC is a major constituent of inland waters, which influences many characteristics of gaseous and nutrient availability and serves as an indicator of organic productivity. DIC also influences water quality properties such as acidity, hardness and related characteristics (Wetzel, 2001). Thus, it is necessary to evaluate the rudiments of DIC reactivity (Tranvik et al., 2009; C. C. Song et al., 2011).

As far as the role of DOM in carbon cycling is concerned, a number of key questions need to be addressed - for example, the origin of DOM, conversion of DOC to DIC, and $\mathrm{CO}_{2}$ outgassing from various inland waters (Cole et al., 2007; Sobek et al., 2007; Jaffé et al., 2008; Tranvik et al., 2009). The spatiotemporal dynamics of dissolved carbon and its association with terrestrial inputs for inland aquatic ecosystems in semi-arid environments have only been investigated in a few regions (Brooks and Lemon, 2007; Mattsson et al., 2009; Moore et al., 2011). Further study is needed for characterizing dissolved carbon in inland saline waters (Duarte et al., 2008; Tranvik et al., 2009), and quantifying the role of inland saline waters for carbon cycling (Cole et al., 2007; Duarte et al., 2008). DOC and DIC concentrations in inland waters are regulated by a combination of parameters. While these parameters vary in both time and space within and across ecosystems, they can be captured by the analysis of optical properties. The objectives of this study were as follows: (1) to investigate the spatial variations of DOC and DIC in the semi-humid and semiarid region; (2) to examine the seasonal characteristics of DOC and DIC; and (3) to perform a DOM source analysis using the relationship between optical absorption indices and salinity.

\section{Materials and methods}

\subsection{Study area}

The Songnen Plain is located in the central region of northeast China, covering an area of approximate $22.3 \times 10^{4} \mathrm{~km}^{2}$ $\left(42^{\circ} 49^{\prime}-49^{\circ} 12^{\prime} \mathrm{N}, 121^{\circ} 38^{\prime}-128^{\circ} 30^{\prime} \mathrm{E}\right.$; Fig. 1). It is a fluvial plain formed by the Songhua and Nenjiang rivers and their tributaries originating from the surrounding mountains: the Changbai (east), Lesser Xing'an (north) and Great Xing' an (west) mountain ranges. The plain is characterized by a temperate, semi-humid and semi-arid continental monsoon climate, with seasons alternating between dry and windy spring; humid and warm summer; windy and dry autumn; and long, cold and dry winter (Song et al., 2010; Zeng et al., 2011). The air temperature increases from north to south, spanning from 2 to $6^{\circ} \mathrm{C}$. The average annual precipitation ranges from 350 to $600 \mathrm{~mm}$, of which more than $80 \%$ of the precipitation occurs in growing season (from May to October). The potential evaporation exceeds $1300 \mathrm{~mm} \mathrm{yr}^{-1}$, resulting in water scarcity. Due to its geomorphology, many terminal-flow areas and temporary waters are formed, which result in widely distributed fresh and saline water bodies in the plain. These lakes in mid-west of the plain were formed in a similar geological and climatic environment (K. S. Song et al., 2011), and waters tend to be brackish. Particularly, these terminal waters have no outflow (Table 1) due to saline and 

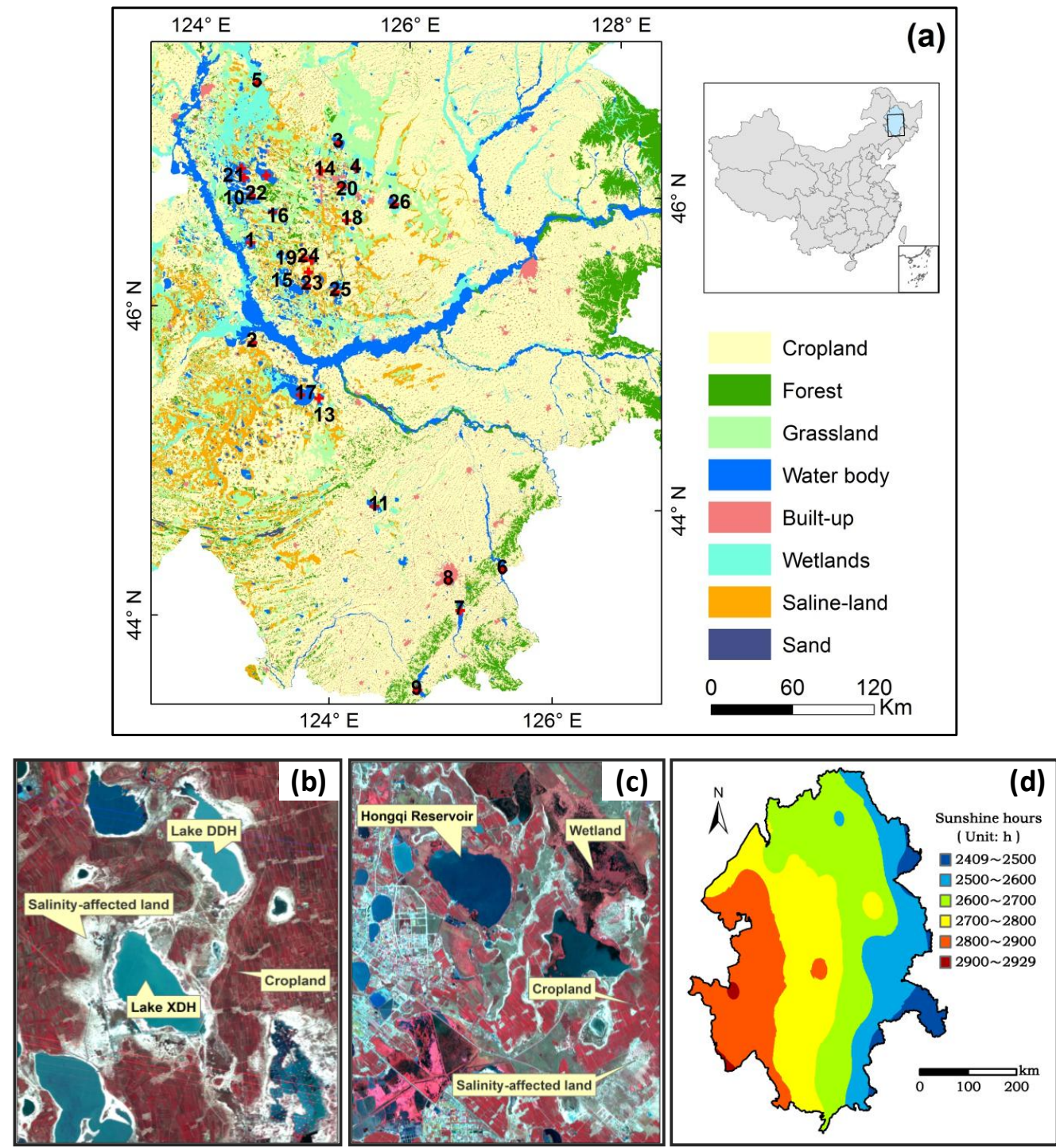

Fig. 1. (a) Map of sampling locations with various land use/land cover types. The fresh waters are the following: 1 - Lamasi, 2 - Yueliang Lake, 3 - Daqing Reservoir, 4 - Hongqi Reservoir, 5 - Dongsheng Reservoir, 6 - Shitoukoumen Reservoir, 7 - Xinlicheng, 8 - Nanhu Lake, 9 - Erlonghu, 10 - Talahong Reservoir, 11 - Boluo Lake, 12 - Longhupao Lake, 13 - Xinmiao Lake, 14 - Yueliangpao; brackish waters are the following: 15 - Xidahai, 16 - Yuebingpao, 17 - Chagan Lake, 18 - Zhongneipao, 19 - Dongdahai, 20 - Zhaojiatun, 21 - Cuibaguzi, 22 - Huoshaohei, 23 - Nanyin Reservoir, 24 - Xinhua Lake, 25 - Kulipao, and 26 - Qingkenpao. (b) Lake Dongdahai and Xidahai, (c) Hongqi Reservoir with their ambient environments, and (d) sunshine duration characteristics for the Songnen Plain.

alkaline soil erosion (Fig. 1a-c). A total of 14 fresh (open water) waters and 12 brackish (terminal) waters were chosen for this study (threshold value $=1000 \mu \mathrm{S} \mathrm{cm}^{-1}$ was set to group fresh and brackish waters, Table 1) with respect to both climatic-hydrologic conditions and lake size. Note that Nanhu Lake (NHL) is located in Changchun City, and some sewage outlets are connected with it.

\subsection{Water sampling and quality determination}

A total of 26 water bodies were sampled from late August to early October 2011 for spatially characterizing dissolved carbon. Altogether, 211 samples were collected, and the sample numbers for each water body are listed in Table 1 . Six field surveys were conducted across the Shitoukoumen Reservoir (fresh water: 109 samples) and Chagan Lake (brackish water: 107 samples) respectively to examine the seasonal characteristics during 2008-2011. Surface water samples were collected at each station approximately $0.5 \mathrm{~m}$ below the water surface, generally located in the middle of water bodies. All water samples were kept in a portable refrigerator powered by field trip vehicles. All samples were filtered within $24 \mathrm{~h}$ after coming back from the field. 
Table 1. Lake (or reservoir) names, abbreviation (with numbers), sampling dates, mean water surface area, water volume, water depth, inflow and outflow conditions, $\mathrm{pH}$ value, salinity and sampling numbers for waters across the Songnen Plain.

\begin{tabular}{|c|c|c|c|c|c|c|c|c|c|c|}
\hline Lake name & $\begin{array}{l}\text { Abbr. } \\
\text { (number) }\end{array}$ & Date & $\begin{array}{r}\text { Area } \\
\left(\mathrm{km}^{2}\right)\end{array}$ & $\begin{array}{l}\text { Volume } \\
\left(10^{8} \mathrm{~m}\right)\end{array}$ & $\begin{array}{r}\text { Depth } \\
(\mathrm{m})\end{array}$ & In- $F^{\mathrm{a}}$ & Out-F $F^{b}$ & $\mathrm{pH}$ & $\begin{array}{r}\text { Salinity } \\
\text { (PSU) }\end{array}$ & $N$ \\
\hline Lamasi & LMS (1) & 24 September 2011 & 51 & 1.52 & 3 & $\mathrm{P}$ & $\mathrm{Y}$ & 8.46 & 0.09 & 5 \\
\hline Yueliang Lake & YLL (2) & 1 September 2011 & 206.1 & 4.74 & 3.6 & $\mathrm{R}+\mathrm{P}$ & $\mathrm{Y}$ & 7.93 & 0.1 & 20 \\
\hline Daqing & DQR (3) & 8 September 2011 & 56.1 & 1.03 & 1.3 & $\mathrm{C}+\mathrm{P}$ & $\mathrm{Y}$ & 8.14 & 0.1 & 5 \\
\hline Hongqi & HQR (4) & 9 September 2011 & 26.2 & 0.83 & 2.8 & $\mathrm{C}+\mathrm{P}$ & $\mathrm{Y}$ & 8.36 & 0.11 & 3 \\
\hline Dongsheng & DSR (5) & 25 September 2011 & 7.8 & 0.31 & 3.2 & $\mathrm{C}+\mathrm{P}$ & $\mathrm{Y}$ & 8.05 & 0.11 & 5 \\
\hline Shitoukoumen & STR (6) & 2008-2010 \# & 73.3 & 3.86 & 7.5 & $\mathrm{R}+\mathrm{P}$ & $\mathrm{Y}$ & 8.09 & 0.13 & 15 \\
\hline Xinlicheng & XLC (7) & 20 September 2011 & 58.5 & 5.92 & 7.6 & $\mathrm{R}+\mathrm{P}$ & $\mathrm{Y}$ & 8.57 & 0.14 & 20 \\
\hline Nanhu & NHL (8) & 26 September 2011 & 1 & 0.03 & 3.7 & $\mathrm{SW}+\mathrm{R}$ & $\mathrm{Y}$ & 8.28 & 0.15 & 8 \\
\hline Erlonghu & ELL (9) & 19 September 2011 & 89.5 & 1.76 & 11.6 & $\mathrm{R}+\mathrm{P}$ & $\mathrm{Y}$ & 8.23 & 0.16 & 21 \\
\hline Talahong & TLR (10) & 16 September 2011 & 71.6 & 1.89 & 1.8 & $\mathrm{R}+\mathrm{P}$ & $\mathrm{Y}$ & 8.64 & 0.24 & 4 \\
\hline Boluohu & BLL (11) & 25 August 2011 & 49.3 & 0.9 & 1.3 & $\mathrm{R}+\mathrm{P}$ & $\mathrm{Y}$ & 8.6 & 0.25 & 8 \\
\hline Longhupao & LHP (12) & 23 September 2011 & 130.8 & 1.75 & 2.7 & $\mathrm{R}+\mathrm{P}$ & $\mathrm{Y}$ & 8.09 & 0.37 & 10 \\
\hline Xinmiao & XML 13) & 30 August 2011 & 31.6 & 0.62 & 2.1 & $\mathrm{C}+\mathrm{P}$ & $\mathrm{Y}$ & 9.12 & 0.46 & 10 \\
\hline Yueliangpao & YLP (14) & 7 September 2011 & 1.1 & 0.07 & 1.5 & $\mathrm{R}+\mathrm{P}$ & $\mathrm{N}$ & 7.78 & 0.48 & 3 \\
\hline Xidahai & $\mathrm{XDH}(15)$ & 14 September 2011 & 12.5 & 0.46 & 1.6 & $\mathrm{P}$ & $\mathrm{N}$ & 8.97 & $0.52+$ & 3 \\
\hline Yuebingpao & YBP (16) & 22 September 2011 & 23 & 0.57 & 2.5 & $\mathrm{P}$ & $\mathrm{N}$ & 8.92 & $0.54+$ & 3 \\
\hline Chagan & CGL (17) & 2008-2011\# & 375.2 & 6.42 & 2.2 & $\mathrm{C}+\mathrm{P}$ & $\mathrm{N}$ & 9.12 & $0.57+$ & 15 \\
\hline Zhongneipao & ZNP (18) & 10 September 2011 & 13.6 & 0.55 & 1.7 & $\mathrm{C}+\mathrm{P}$ & $\mathrm{N}$ & 9.09 & $0.65+$ & 10 \\
\hline Dongdahai & DDH (19) & 14 September 2011 & 16.5 & 0.25 & 0.4 & $\mathrm{P}$ & $\mathrm{N}$ & 8.91 & $0.66+$ & 5 \\
\hline Zhaojiatun & ZJT (20) & 8 September 2011 & 5.6 & 0.17 & 0.7 & $\mathrm{P}$ & $\mathrm{N}$ & 8.42 & $0.68+$ & 4 \\
\hline Cuibaguzi & CBG (21) & 25 September 2011 & 58.4 & 1.12 & 1.4 & $\mathrm{P}$ & $\mathrm{N}$ & 9.35 & $0.71+$ & 1 \\
\hline Huoshaohei & HSH (22) & 17 September 2011 & 73.4 & 1.92 & 2.5 & $\mathrm{P}$ & $\mathrm{Y}$ & 9.28 & $0.73+$ & 4 \\
\hline Nanyin & NYR (23) & 15 September 2011 & 47.1 & 1.05 & 2.1 & $\mathrm{C}+\mathrm{P}$ & $\mathrm{N}$ & 9.17 & $0.95+$ & 4 \\
\hline Xinhuahu & XHL (24) & 14 September 2011 & 7.4 & 0.18 & 1.3 & $\mathrm{P}$ & $\mathrm{N}$ & 9.33 & $1.25+$ & 3 \\
\hline Kulipao & KLP (25) & 15 September 2011 & 33.7 & 0.71 & 2.1 & $\mathrm{R}+\mathrm{P}$ & $\mathrm{N}$ & 9.27 & $1.42+$ & 5 \\
\hline Qingkenpao & QKP (26) & 11 September 2011 & 33.1 & 0.73 & 1 & $\mathrm{C}+\mathrm{P}$ & $\mathrm{N}$ & 9.33 & $1.51+$ & 5 \\
\hline
\end{tabular}

a denotes the major inflow type, $\mathrm{R}=$ river, $\mathrm{C}=$ channel, $\mathrm{P}=$ precipitation, $\mathrm{SW}=$ sewage; ${ }^{\mathrm{b}}$ denotes the out flow type, $\mathrm{Y}=$ yes, $\mathrm{N}=$ no; \# indicates that multiple field campaigns were conducted across these waters; + indicates brackish waters.

Water turbidity was determined using a Shangfen Vis7230 spectrophotometer with a $3 \mathrm{~cm}$ quartz cell at room temperature $\left(20 \pm 2^{\circ}\right)$ with Milli-Q water as reference. Salinity was measured through DDS-307 electrical conductivity (EC) meter with $\mu \mathrm{S} \mathrm{cm}^{-1}$ (micro-Siemens/centimeter) units at room temperature $\left(20 \pm 2^{\circ}\right)$ in the laboratory. Chlorophyll $a$ (Chl $a$ ) concentration was determined using a Shimadzu UV2550PC spectrophotometer (K. S. Song et al., 2011). Total suspended matter (TSM) was determined gravimetrically; details can be found in Song et al. (2013). Total nitrogen (TN) was measured based on the absorption levels at $146 \mathrm{~nm}$ of water samples decomposed with alkaline potassium peroxydisulfate. Total phosphorus (TP) was determined using the molybdenum blue method after the samples were digested with potassium peroxydisulfate (APHA, 1998). To determine DOC concentrations, water samples were filtered through pre-combusted $0.45 \mu \mathrm{m} \mathrm{GF/F} \mathrm{filters.} \mathrm{The} \mathrm{standards}$ for dissolved total carbon (DTC) were prepared from reagent grade potassium hydrogen phthalate in ultra-pure water, while DIC levels were determined using a mixture of anhydrous sodium carbonate and sodium hydrogen carbonate.
DOC was calculated by subtracting DIC from DTC, both of which were measured by high-temperature catalytic oxidation $\left(680^{\circ} \mathrm{C}\right)$ using a total organic carbon analyzer (Shimadzu, TOC-VCPN). To validate the association between salinity and DOC and DIC, 153 independent samples across 26 water bodies were analyzed in May, 2012.

\subsection{CDOM laboratory analysis}

In laboratory, samples were filtered at low pressure through pre-combusted GF/F filters, and then through a pre-rinsed Millipore membrane cellulose filter $(0.22 \mu \mathrm{m})$ for CDOM absorption measurement. Absorption spectra were obtained in the 200 to $800 \mathrm{~nm}$ spectral region at $1 \mathrm{~nm}$ increments using a Shimadzu UV-2550PC UV-Vis dual beam spectrophotometer with $1 \mathrm{~cm}$ quartz cuvettes. Milli-Q water was used as reference for CDOM absorption measurements. The absorption coefficient $\left(a_{\mathrm{CDOM}}\right)$ was calculated from the measured optical density (OD) of the sample using Eq. (1):

$a_{\mathrm{CDOM}}(\lambda)=2.303\left[\mathrm{OD}_{S(\lambda)}-O D_{(\mathrm{null})}\right] / \gamma$, 
where $\gamma$ is the cuvette path length $(0.01 \mathrm{~m})$ and 2.303 is the conversion factor. Some fine particles may have remained in the filtrate and necessitated correction for scattering by fine particles (Babin et al., 2003). OD (null) $_{\text {is }}$ the average optical density over $740-750 \mathrm{~nm}$, where the absorbance of CDOM was assumed to be zero. All absorption measurements were conducted within $48 \mathrm{~h}$ of field sampling. The CDOM absorption ratio, $E_{250: 365}$, was calculated using absorbance at $250 \mathrm{~nm}$ and $365 \mathrm{~nm}$. The specific UV absorbance at $254 \mathrm{~nm}$ $\left(\mathrm{SUVA}_{254}\right)$ is defined as the absorbance at $254 \mathrm{~nm}\left(\mathrm{~m}^{-1}\right)$ divided by the DOC concentration $\left(\mathrm{mg} \mathrm{L}^{-1}\right)$ (Weishaar et al., 2003).

\subsection{Spectral slope $(S)$}

A CDOM absorption spectrum, $a_{\mathrm{CDOM}}(\lambda)$, can be expressed as an exponential function (Bricaud et al., 1995; Babin et al., 2003):

$a_{\mathrm{CDOM}}\left(\lambda_{i}\right)=a_{\mathrm{CDOM}}\left(\lambda_{\mathrm{r}}\right) \exp \left[-S\left(\lambda_{i}-\lambda_{\mathrm{r}}\right)\right]$,

where $a_{\mathrm{CDOM}}\left(\lambda_{i}\right)$ is the CDOM absorption at a given wavelength $\lambda_{i}, a_{\mathrm{CDOM}}\left(\lambda_{\mathrm{r}}\right)$ is the absorption estimate at a reference wavelength $\lambda_{\mathrm{r}}(440 \mathrm{~nm})$, and $S$ is the spectral slope. $S$ is calculated by fitting the data to a nonlinear model over a wavelength range of 300 to $500 \mathrm{~nm}$, as suggested by Zepp and Schlotzhauer (1981) and Zhang et al. (2007). Different $S$ values may be obtained due to different curve-fitting approaches and spectral ranges (Babin et al., 2003; Binding et al., 2008; Astoreca et al., 2009). The Sr was calculated to determine CDOM sources (Helms et al., 2008).

\subsection{Statistical analysis}

Statistical analyses were conducted using SPSS 16.0 software package (Statistical Program for Social Sciences). The differences in DOC, DIC, CDOM and relevant spectral indices were assessed with ANOVA (paired $t$ test). Both $p$ value $(\alpha)$ and statistical power (power $=1-\beta$ ) were calculated for a comparison of brackish and fresh waters in the plain.

\section{Results}

The analysis of the water samples collected from the 26 water bodies in the Songnen Plain indicated that these water bodies had quite diverse water qualities. Most of these water bodies exhibited high $\mathrm{TN}$ concentrations (mean $\pm \mathrm{SD}$, $3.25 \pm 1.86 \mathrm{mg} \mathrm{L}^{-1}$ ), and only two lakes contained average $\mathrm{TN}$ levels less than $1.0 \mathrm{mg} \mathrm{L}^{-1}$ (Table 2). Similarly, TP levels exhibited high variability, ranging from 0.06 to $1.86 \mathrm{mg} \mathrm{L}^{-1}$ $\left(0.44 \pm 0.52 \mathrm{mg} \mathrm{L}^{-1}\right)$. As expected, high $\mathrm{Chl} a$ concentrations $\left(48.44 \pm 39.71 \mu \mathrm{g} \mathrm{L}^{-1}\right)$ were observed in these water bodies. According to Carlson's trophic index (1977), $85 \%$ of the water bodies were eutrophic or hypereutrophic (Zhang et
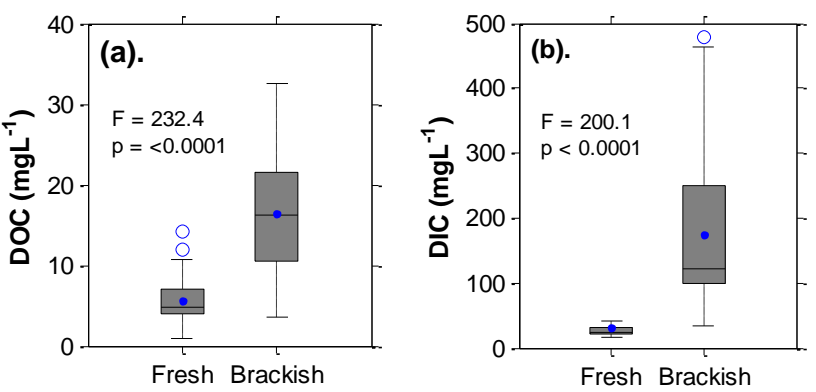

Fig. 2. Box plots of DOC (a) and DIC (b) for fresh and brackish waters in the Songnen Plain. The black line and the blue filled circles represent the median and mean respectively. The horizontal edges of the boxes denote the 25 th and 75 th percentiles; the whiskers denote the 10th and 90th percentiles and the blue circles represent outliers.

al., 2010), and the remaining $15 \%$ were mesotrophic. Agricultural non-point pollution was the main source of $\mathrm{TN}$ and TP for these water bodies, resulting in algal blooms in some of the waters (Wang et al., 2009; K. S. Song et al., 2011). Due to regional hydro-geologic and climatic conditions, most of water bodies in the western Songnen Plain had high salt contents and $\mathrm{pH}$ values. Overall, these water bodies were highly turbid $(87.0 \pm 101.4 \mathrm{NTU})$, with a high concentration of TSM $\left(119.55 \pm 131.37 \mathrm{mg} \mathrm{L}^{-1}\right)$ in the water column (Table 2). This could be attributed to strong winds in spring and autumn causing re-suspension of the bottom sediments.

\subsection{Dissolved carbon spatial characteristics}

The DOC concentrations in fresh waters ranged from $1.01 \mathrm{mg} \mathrm{L}^{-1}$ in Longhupao Lake (LHP) to $14.23 \mathrm{mg} \mathrm{L}^{-1}$ in Boluo Lake (BLL) (see Table 2). A large variation of DOC concentration was revealed in the brackish waters, ranging from $3.6 \mathrm{mg} \mathrm{L}^{-1}$ in Nanyin Reservoir (NYR) to $32.6 \mathrm{mg} \mathrm{L}^{-1}$ in Zhongneipao (ZNP). The brackish waters exhibited higher average DOC concentrations $(16.4 \pm$ $\left.7.4 \mathrm{mg} \mathrm{L}^{-1}\right)$ than fresh waters $\left(5.6 \pm 2.4 \mathrm{mg} \mathrm{L}^{-1}\right)$. A significant difference was observed between these two water types $(F=232.4, p<0.0001$, power $=1.0$, Fig. $2 \mathrm{a})$, and the interquartile ranges (IQR) for the fresh and brackish waters are 2.91 and 11.31, respectively. A large variation of DIC concentrations in the fresh waters was observed, ranging from $16.2 \mathrm{mg} \mathrm{L}^{-1}$ over Shitoukoumen Reservoir (STR) in eastern part of the plain to $125.4 \mathrm{mg} \mathrm{L}^{-1}$ in Huoshaohei (HSH) in western Songnen Plain (Fig. 1). The DIC concentrations for the brackish waters ranged from $37.2 \mathrm{mg} \mathrm{L}^{-1}$ (ZJT) to $482.4 \mathrm{mg} \mathrm{L}^{-1}$ (DDH). Concentrations of DIC were higher in the brackish waters $\left(173.5 \pm 110.4 \mathrm{mg} \mathrm{L}^{-1}\right)$ than the fresh water $\left(32.0 \pm 24.3 \mathrm{mg} \mathrm{L}^{-1}\right)$. A significant difference for DIC was observed between the brackish and fresh waters $(p<0.0001$, power $=1.0$, Fig. $2 b)$. Higher IQR values were recorded with brackish water (151.07) than fresh water (9.53). Interestingly, the fresh waters showed a higher 
Table 2. Mean values of water quality parameters and CDOM absorption from late August to late September. TN and TP denote total nitrogen and total phosphorus, respectively. Chl $a$ denotes chlorophyll $a$ concentration. TSM denotes total suspended matter, and Turb denotes water turbidity. DOC and DIC are dissolved organic and inorganic carbon respectively. "-" indicates no available data.

\begin{tabular}{|c|c|c|c|c|c|c|c|c|c|}
\hline $\begin{array}{l}\text { Lake } \\
\text { Abbr }\end{array}$ & $\begin{array}{r}\mathrm{TN} \\
\left(\mathrm{mg} \mathrm{L}^{-1}\right)\end{array}$ & $\begin{array}{r}\mathrm{TP} \\
\left(\mathrm{mg} \mathrm{L}^{-1}\right)\end{array}$ & $\begin{array}{r}\text { Chl } a \\
\left(\mu \mathrm{g} \mathrm{L}^{-1}\right)\end{array}$ & $\begin{array}{r}\text { TSM } \\
\left(\mathrm{mg} \mathrm{L}^{-1}\right)\end{array}$ & $\begin{array}{r}\text { Turb } \\
(\mathrm{NTU})\end{array}$ & $\begin{array}{r}a_{\mathrm{CDOM}}(355) \\
\left(\mathrm{m}^{-1}\right)\end{array}$ & $\begin{array}{r}a_{\mathrm{CDOM}}(440) \\
\left(\mathrm{m}^{-1}\right)\end{array}$ & $\mathrm{DOC}$ & DIC \\
\hline LMS & 0.96 & 0.02 & 17.6 & 39.9 & 52.1 & 5.04 & 1.46 & 9.15 & 23.42 \\
\hline YLL & 9.77 & 1.86 & 55.7 & 44 & 51.4 & 25.45 & 10.39 & 8.79 & 25.48 \\
\hline DQR & 2.08 & 0.07 & 11.7 & 40.2 & 37.6 & 5.69 & 1.48 & 5.23 & 30.13 \\
\hline HQR & 5.28 & 1.01 & 18.1 & 17.7 & 24.3 & 7.56 & 1.57 & 5.71 & 28.05 \\
\hline DSR & 5.4 & 1.72 & 136.4 & 44.6 & 22.4 & 16.91 & 4.25 & 5.55 & 30.84 \\
\hline STR & 1.6 & 0.06 & 23.4 & 35.7 & 37.8 & 2.88 & 0.77 & 4.74 & 16.23 \\
\hline XLC & 0.89 & 0.06 & 14.3 & 8.1 & 10.7 & 3.08 & 0.82 & 3.83 & 21.13 \\
\hline NHL & 2.15 & 0.14 & 20.2 & 80.4 & 10.3 & 8.66 & 2.53 & 5.08 & 20.15 \\
\hline ELL & 1.94 & 0.13 & 60.7 & 14 & 7.3 & 3.45 & 0.96 & 4.21 & 22.59 \\
\hline TLR & 4.42 & 1.21 & 52 & 554.6 & 97.2 & 11.9 & 3.06 & 6.36 & 74.59 \\
\hline BLL & 4.37 & 1.13 & 48.5 & 402.6 & 44.8 & 31.33 & 15.22 & 9.69 & 88.98 \\
\hline LHP & 3.5 & 0.48 & 59.9 & 258.9 & 64.5 & 26.32 & 10.65 & 2.72 & 33.43 \\
\hline XML & - & - & 28.5 & 80.8 & 21.2 & 9.04 & 2.84 & 4.15 & 23.17 \\
\hline YLP & 2.51 & 0.57 & 9.4 & 29.5 & 23.9 & 11.17 & 2.3 & 6.36 & 74.58 \\
\hline $\mathrm{XDH}$ & 1.91 & 0.03 & 31.7 & 20.9 & 366.8 & 7.35 & 1.38 & 14.92 & 244.53 \\
\hline YBP & 2.41 & 0.2 & 43.1 & 63.3 & 149.6 & 3.64 & 0.52 & 19.97 & 111.53 \\
\hline CGL & 2.78 & 0.43 & 46.3 & 65.7 & 88.5 & 8.37 & 1.69 & 9.98 & 98.25 \\
\hline ZNP & 2.17 & 0.1 & 14.1 & 110.3 & 27.8 & 6.91 & 1.33 & 29.78 & 124.36 \\
\hline $\mathrm{DDH}$ & 4.9 & 0.13 & 185.7 & 45.2 & 408.5 & 8.77 & 1.97 & 28.44 & 442.78 \\
\hline ZJT & 4.45 & 0.17 & 96.8 & 143.3 & 11.7 & 16.64 & 5.56 & 14.44 & 82.11 \\
\hline CBG & 1.09 & 0.079 & 35.2 & 23.8 & 264.3 & 5.96 & 2.28 & 18.57 & 233.75 \\
\hline $\mathrm{HSH}$ & 1.82 & 0.075 & 39.7 & 25.2 & 132.4 & 9.49 & 4.13 & 7.33 & 125.35 \\
\hline NYR & 1.04 & 0.55 & 29.4 & 5.6 & 124.3 & 2.05 & 0.75 & 6.85 & 54.81 \\
\hline XHL & 3.75 & 0.24 & 33.5 & 113.8 & 47.2 & 3.06 & 0.43 & 14.92 & 244.50 \\
\hline KLP & 5.96 & 0.41 & 88 & 311 & 23.4 & 15.37 & 5.23 & 16.86 & 106.45 \\
\hline QKP & 4.18 & 0.15 & 59.5 & 129.3 & 112.2 & 6.92 & 1.29 & 20.56 & 285.23 \\
\hline
\end{tabular}

mean DOC/DIC ratio $(0.33 \pm 0.13)$ than the brackish water $(0.21 \pm 0.14)$.

\subsection{CDOM spatial characterization}

As shown in Table 2, the mean value of $\mathrm{SUVA}_{254}$ ranged from $2.3 \mathrm{~L} \mathrm{mg} \mathrm{C}^{-1} \mathrm{~m}^{-1}( \pm 0.14 \mathrm{SD})$ in Nanhu Lake (NHL) to $8.7 \mathrm{~L} \mathrm{mg} \mathrm{C}^{-1} \mathrm{~m}^{-1}$ ( $\pm 2.8 \mathrm{SD}$ ) in Huoshaohei (HSH). The small mean $\mathrm{SUVA}_{254}$ value was observed in the brackish waters, ranging from $2.8 \mathrm{~L} \mathrm{mg} \mathrm{C}^{-1} \mathrm{~m}^{-1}( \pm 0.06 \mathrm{SD})$ in the Chagan Lake (CGL) to $5.7 \mathrm{~L} \mathrm{mg} \mathrm{C}^{-1} \mathrm{~m}^{-1}( \pm 0.98 \mathrm{SD}$ ) in the Yuebingpao (YBP). This indicates a significant difference in $\mathrm{SUVA}_{254}$ between the fresh and brackish waters (Fig. 3a, $p<0.0001$, power $=1.0$ ). The IQR values are 2.00 and 1.41 for the fresh and brackish waters, respectively. The averaged $\mathrm{SUVA}_{254}$ was higher in the fresh waters $\left(5.8 \mathrm{~L} \mathrm{mg} \mathrm{C}^{-1} \mathrm{~m}^{-1} \pm 1.72 \mathrm{SD}\right)$ than the brackish waters $\left(3.8 \pm 1.04 \mathrm{~L} \mathrm{mg} \mathrm{C}^{-1} \mathrm{~m}^{-1}\right)$.

The averaged $E_{250: 365}$ ranged from $5.5( \pm 1.46 \mathrm{SD})$ in Xinmiao Lake (XML) to $10.3( \pm 0.27 \mathrm{SD})$ in Huoshaohei (HSH) for the fresh water (Table 2), but a large range for $E_{250: 365}$ was obtained for the brackish waters, ranging from $7.5 \pm 0.10$ in Kulipao (KLP) to $15.8 \pm 1.43$ in Xinmiao Lake
(XML). This suggests a significant difference $(p<0.0001$, power $=0.999$, Fig. $3 b$ ) between the fresh and the brackish waters in $E_{250: 365}$. IQR for the brackish water (5.67) was higher than the fresh water (1.17).

As shown in Table 2, the averaged $\mathrm{Sr}$ for the fresh waters ranged from $0.80 \pm 0.021$ in Daqing Reservoir (DQR) to $1.46 \pm 0.046 \mathrm{SD}$ in Nanhu Lake (NHL). Comparatively, a larger range for $\mathrm{Sr}$ was obtained for the brackish waters, ranging from $1.32( \pm 0.006 \mathrm{SD})$ in Kulipao (KLP) to 2.1 $( \pm 0.123 \mathrm{SD})$ in Xidahai Lake (XDH). The Sr values exhibited an obvious difference for the fresh and brackish waters (Fig. 3c, $p<0.0001$, power $=0.999$ ), in which the averaged Sr values were $1.09 \pm 0.17$ and $1.41 \pm 0.32$ for the fresh and brackish waters, respectively. IQR value for the fresh water was lower (0.21) than that for the brackish water $(0.36)$.

\subsection{Seasonal variation}

\subsubsection{Dissolved carbon}

The water quality characteristics in both STR and CGL are shown in Table 3. Apparent seasonal variations were observed for TN, TP, Chl $a$ and TSM concentration in both 

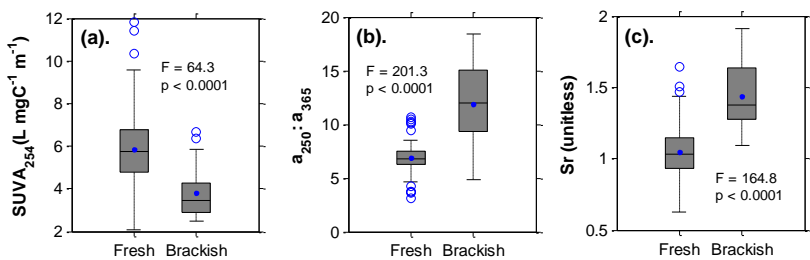

Fig. 3. Box plots of (a) $\mathrm{SUVA}_{254}$, (b) CDOM ratio $\left(a_{250}: a_{365}\right)$ and (c) spectral slope ratio (Sr: $S_{275-295}: S_{350-400} \mathrm{~nm}$ ) between fresh and brackish waters in the Songnen Plain. The black line and the blue filled circles represent the median and mean respectively. The horizontal edges of the boxes denote the 25 th and 75 th percentiles; the whiskers denote the 10th and 90th percentiles and the blue circles represent outliers.

water bodies. Salinity, $\mathrm{pH}$, and the CDOM absorption for the CGL were observed higher than that those for the STR (Table 3). As shown in Fig. 4a, the DOC concentrations in the STR were lower than the CGL in the growing season. Higher DOC concentrations were observed in May for both the STR and CGL, and lower DOC concentrations were observed from May to October in the STR (Fig. 4a). In contrast, the CGL has higher DOC concentrations in the May and October, and lower values in July, August and September for (Fig. 4a).

As illustrated in Fig. 4b, the overall DIC concentration in the CGL was significantly higher than that from the STR $(F=337.2, p<0.0001)$. However, higher DIC was observed in May for the STR, which is consistent with the DOC concentration illustrated in Fig. 4a. Likewise, a higher DIC variation was observed in May for the STR, but small variation values were observed for the other months. The CGL showed high DIC concentrations with less seasonality, except for June and August (Fig. 4b). The samples in June and August revealed a relatively large variation, but small variations in September and October.

\subsubsection{CDOM temporal characterization}

As illustrated in Table 3, the CGL exhibited significantly higher $a_{\mathrm{CDOM}}(355)$ values $\left(17.5 \pm 12.03 \mathrm{~m}^{-1}\right)$ than the STR $\left(5.6 \pm 0.72 \mathrm{~m}^{-1} ; p<0.003\right)$. Likewise, significant differences in the $a_{\mathrm{CDOM}}$ (440) were found between the CGL and STR $(p<0.001)$. As shown in Fig. 5a, the STR and CGL exhibited higher $\mathrm{SUVA}_{254}$ values in May, but in other months the $\mathrm{SUVA}_{254}$ in the CGL showed smaller values and less variation than that in the STR (Fig. 5a). Overall, a significant difference of $\mathrm{SUVA}_{254}$ between the fresh and brackish waters during ice-free season was observed $(p<0.0001$, power $=0.999$ )

While $E_{250: 365}$ generally increased from May to October in the CGL (Fig. 5b), $E_{250: 365}$ values for the STR were relatively stable through all months except for May. Low $E_{250: 365}$ values were recorded in May and June for the CGL.
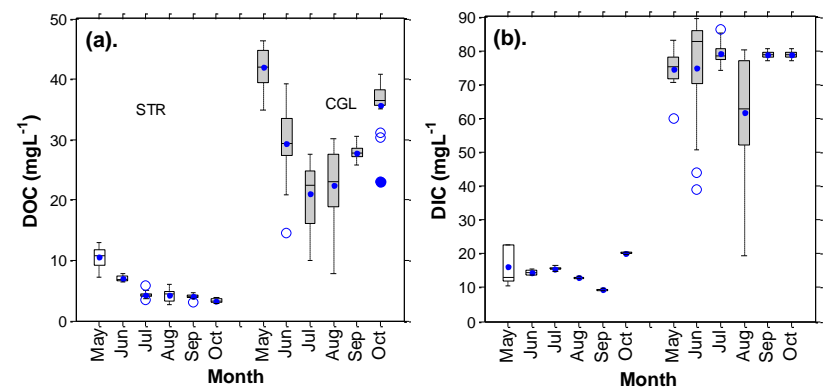

Fig. 4. Box plots of dissolved carbon in fresh and brackish waters during ice-free season: (a) DOC and (b) DIC for Shitoukoumen Reservoir (STR) and Chagan Lake (CGL). The black line and the blue filled circles represent the median and mean respectively. The horizontal edges of the boxes denote the 25th and 75th percentiles; the whiskers denote the 10th and 90th percentiles and the blue circles represent outliers.

Overall increased $\mathrm{Sr}$ values were observed in the STR and CGL (Fig. 5c). It can be seen that the Sr values followed similar trends as shown in $E_{250: 365}$ for both the STR and CGL, while inverse trends were observed for the $\mathrm{SUVA}_{254}$ values. Although a significant difference of $E_{250: 365}$ was revealed between the fresh and brackish waters (Fig. 5b), the difference was not as significant as those demonstrated for SUVA $_{254}$ (Fig. 5a) and Sr (Fig. 5c).

\subsection{Dissolved carbon versus salinity}

As stated above, higher DOC and DIC concentrations were illustrated in the brackish waters in the Songnen Plain with high salinity concentrations due to the terminal aquatic environments, representing terminal points for carbon flow in the terrestrial landscape (Duarte et al., 2008). Regression analyses between salinity and dissolved carbon parameters were conducted on the samples collected in 2011 from 26 water bodies (Fig. 6). The concentrations of DOC in various waters increased with salinity (Fig. $6 \mathrm{a} ; R^{2}=0.66, p<0.001$ ). Likewise, a linear relationship between DIC and salinity was observed (Fig. 6b; $R^{2}=0.94, p<0.0001$ ). To test the stability of the relationship, the correlation of DOC to salinity for the samples in May 2012 is demonstrated in Fig. 6c $\left(R^{2}=0.96, p<0.0001\right)$. Even when four samples with extremely high values (from XDH, see Fig. 1b) were eliminated, a high determination coefficient was still achieved $\left(y=67.25 x+11.216 ; R^{2}=0.79, p<0.0001\right)$. Similarly, a high correlation between DIC and salinity existed (Fig. 6d; $\left.R^{2}=0.98, p<0.0001\right)$. A high $R^{2}$ value was also obtained between DIC and salinity $\left(y=194.74 x+9.66 ; R^{2}=0.91\right.$, $p<0.0001)$ when four samples with extremely high values were excluded. 
Table 3. Seasonal variability of water quality parameters and CDOM absorption features for the Shitoukoumen Reservoir (STR) and for Chagan Lake (CGL); all water quality parameters have the same units as shown in Table 2.

\begin{tabular}{llrrrrrrrrr}
\hline & Date & TN & TP & Chl $a$ & TSM & Salinity & pH & $a_{\text {CDOM }}(355)$ & $a_{\text {CDOM }}(440)$ & $N$ \\
\hline STR 1 & $5 / 20 / 09$ & 2.80 & 0.14 & 12.06 & 60.15 & - & 7.86 & 4.34 & 1.71 & 17 \\
STR 1 & $6 / 13 / 08$ & 1.25 & 0.06 & 24.25 & 21.77 & 0.13 & 8.53 & 6.15 & 2.84 & 18 \\
STR 3 & $7 / 27 / 09$ & 1.03 & 0.12 & 6.98 & 14.51 & 0.13 & 8.43 & 5.32 & 2.06 & 22 \\
STR 4 & $8 / 29 / 09$ & 0.99 & 0.07 & 7.32 & 38.51 & 0.12 & 8.31 & 5.82 & 2.46 & 25 \\
STR 5 & $9 / 23 / 08$ & 1.09 & 0.08 & 35.23 & 23.79 & 0.13 & 8.54 & 5.96 & 2.28 & 20 \\
STR 6 & $10 / 07 / 10$ & 1.17 & 0.09 & 18.7 & 18.7 & 0.13 & 8.71 & 4.57 & 1.83 & 7 \\
Subtotal & - & 1.35 & 0.09 & 17.4 & 35.80 & 0.13 & 8.42 & 5.56 & 2.28 & 109 \\
\hline CGL 1 & $5 / 03 / 11$ & 2.06 & 0.073 & 6.34 & 57.55 & 0.29 & 8.63 & 26.13 & 8.84 & 18 \\
CGL 2 & $6 / 14 / 08$ & 2.01 & 0.13 & 11.6 & 43.2 & 0.37 & 9.07 & 13.5 & 6.87 & 8 \\
CGL 2 & $7 / 15 / 09$ & 3.28 & 0.24 & 14.31 & 190.12 & 0.76 & 9.61 & 34.02 & 19.74 & 20 \\
CGL 3 & $8 / 29 / 09$ & 2.21 & 0.182 & 9.82 & 233.08 & 0.48 & 9.10 & 10.26 & 4.64 & 19 \\
CGL 4 & $9 / 13 / 10$ & 1.82 & 0.075 & 39.67 & 25.19 & 0.66 & 9.30 & 9.49 & 4.13 & 25 \\
CGL 5 & $10 / 12 / 09$ & 1.82 & 0.054 & 4.58 & 66.81 & 0.67 & 9.27 & 6.76 & 2.73 & 17 \\
Subtotal & - & 2.24 & 0.125 & 14.95 & 114.52 & 0.57 & 9.20 & 17.50 & 7.93 & 107 \\
\hline
\end{tabular}
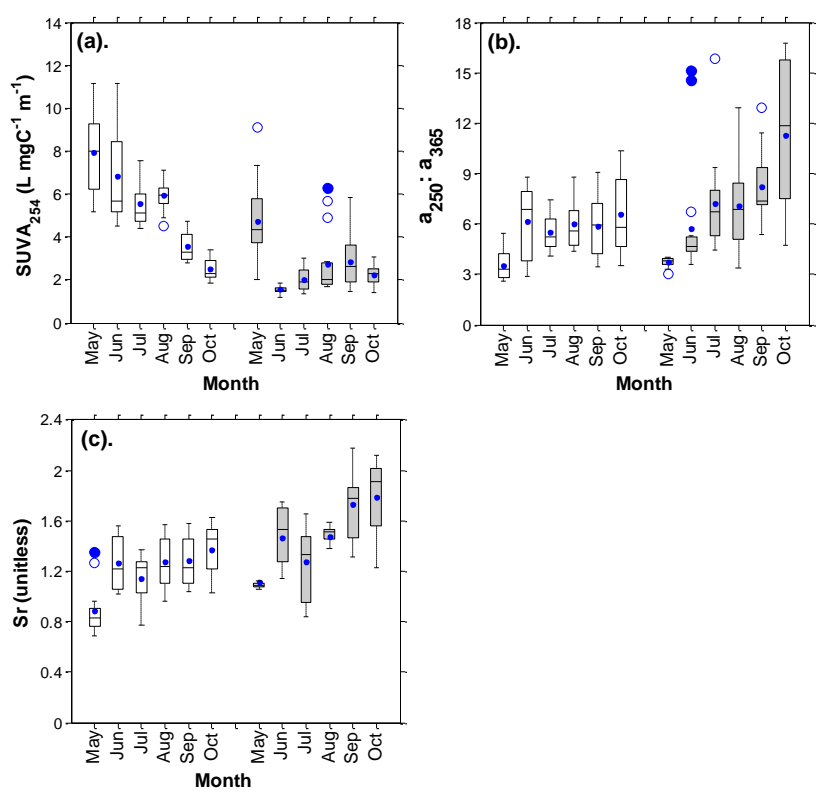

Fig. 5. Box plots of (a) $\mathrm{SUVA}_{254}$, (b) $a_{250}: a_{365}$ and (c) $\mathrm{Sr}$ for Shitoukoumen Reservoir (empty box) and Chagan Lake (filled box) in various seasons. The black line and the blue filled circles represent the median and mean respectively. The horizontal edges of the boxes denote the 25 th and 75 th percentiles; the whiskers denote the 10th and 90th percentiles and the blue circles represent outliers.

\section{Discussion}

\subsection{Dissolved organic carbon in fresh and brackish waters}

In this study, substantial variations for both DOC and DIC are observed between the fresh and brackish waters in the Songnen Plain (Fig. 2). The pattern is similar to that reported by Curtis and Adams (1995) for lakes in east-central Alberta in the semi-arid region of Canada. Seasonally averaged DOC concentrations in the brackish waters are much higher than in the fresh water bodies, indicating that DOC concentration violates the trend in humid regions, with DOC decreasing with water residence time due to prolonged photobleaching and possible dilution (Twardowski and Donaghay, 2002; Julian et al., 2011; Spencer et al., 2012). These findings indicate that regional hydrogeologic and climatic conditions play an important role in driving DOC variability (Sobek et al., 2007; Duarte et al., 2008; Jaffé et al., 2008). In the brackish waters, DOC accumulates via runoff passing through various landscapes (Larson et al., 2007; C. C. Song et al., 2011), and can be lost from these brackish waters through sinking to the bottom (Cole et al., 2007; Tranvik et al., 2009; Barros et al., 2011) or being transformed into DIC (includes $\mathrm{CO}_{2}$ ) in the water column (Brooks and Lemon, 2007; Duarte et al., 2008; Tranvik et al., 2009). Consequently, DOC and DIC accumulate in brackish (terminal) waters at much higher rates than those in fresh (open) waters (Brooks and Lemon, 2007; Duarte et al., 2008).

The DIC concentrations in the brackish waters in the western Songnen Plain are much higher than in the fresh waters in the eastern part of the plain. Comparatively shorter sunlight durations (Zeng et al., 2011) and water residence times (Wang and Dou, 1998) result in lower DIC production and accumulation in fresh waters. As noted, most of the waters in the western Songnen Plain exhibit the limnetic characteristics of shallow plain lakes, which is re-suspension of the loose bottom sediment due to strong wind (see Table 2 for the Kulipao Lake, Nanyin Reservoir and Cuibaguzi Lake). A long sunlight duration in the western part of the Songnen Plain may cause higher DIC concentrations due to enhanced photochemical oxidation processes (Brook and Lemon, 2007; Tobias and Bohlke, 2011), speeding up the 
Table 4. Multi-regression analysis of DOC and DIC against accumulated climatic variables in one month before field surveys were conducted (P, precipitation; $\mathrm{ET}_{0}$, potential evaporation; $\mathrm{S}$, sunshine duration hours) over 26 water bodies across the Songnen Plain.

\begin{tabular}{|c|c|c|c|c|c|c|c|c|}
\hline & \multirow[b]{2}{*}{ Intercept } & \multicolumn{3}{|c|}{ Slope } & \multicolumn{4}{|c|}{ Statistics } \\
\hline & & $\mathrm{P}$ & $\mathrm{ET}_{0}$ & S & $R$ square & Adj.R square & $F$ value & $p$ value \\
\hline DOC & -135.38 & 0.18 & 0.93 & 0.11 & 0.33 & 0.27 & 4.13 & 0.024 \\
\hline DIC & -1823.77 & 2.89 & 0.71 & 5.99 & 0.34 & 0.26 & 3.78 & 0.032 \\
\hline
\end{tabular}
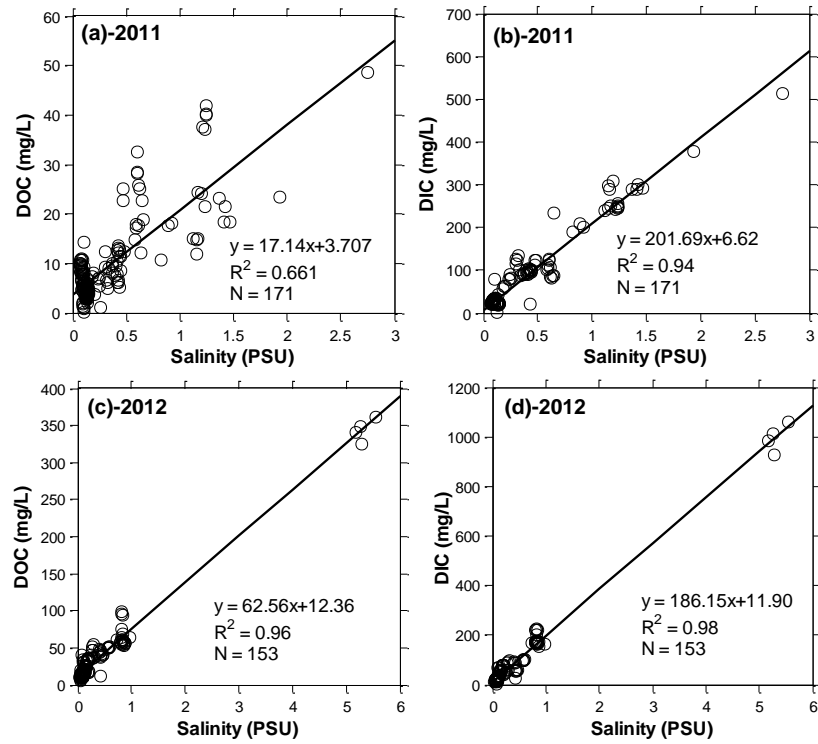

Fig. 6. Correlation between dissolved carbon and salinity (in PSU) in water bodies across the Songnen Plain. (a) DOC vs. salinity and (b) DIC vs. salinity for 2011 data set collected in late summer to early autumn; (c) DOC vs. salinity and (d) DIC vs. salinity with independent samples were collected in spring 2012 to test stability of the relationship between dissolved organic carbon and salinity.

mineralization of DOC in these waters (Granéli et al., 1996; Duarte et al., 2008). Land use may play an important role in the higher DIC levels in these terminal waters due to the saline-alkaline soil around these water bodies (Fig. 1b-c) (Wetzel 2001; Duarte et al., 2008; Wilson and Xenopoulos, 2008; Philips, 2010).

In this study, $\mathrm{SUVA}_{254}$ is proven to be an effective index for characterizing DOC concentrations. The $\mathrm{SUVA}_{254}$ reveals that high molecular weight DOC fractions are abundant in fresh waters due to quick exchange rates of DOC in the water column and less residence time (Spencer et al., 2008, 2012). Due to a long residence time for the brackish waters (Table 1), DOC concentrations increased, even though limited inflow led to decreased DOC transportation compared to humid or semi-humid regions (Duarte et al., 2008). These findings suggest that some DOC inputs can be evapo-concentrated (Curtis and Adams, 1995). Despite the prolonged photo-oxidation or the autochthonous DOC origins, the lower molecular weight DOC fraction is more abundant in brackish waters (Weishaar et al., 2003).

High values of both $E_{250: 365}$ and $\mathrm{Sr}$ are observed in brackish waters, which may be regulated by the DOC flux for inland waters both in time and space (Jaffé et al., 2008; Spencer et al., 2009, 2012; Zhang et al., 2010; Fellman et al., 2011). Nevertheless, the $E_{250: 365}$ and $\mathrm{Sr}$ values are found to be useful for indicating seasonal DOC compositional variations (Fichot and Benner, 2011). Relatively short residence times in fresh waters enhanced terrestrial DOC input, resulting in high molecular weight DOC fractions (Table 1). In contrast, long irradiation times in mid-west of the Songnen Plain generally decreased the high molecular weight fractions (Helms et al., 2008). Note that the special behavior of $\mathrm{SUVA}_{254}$, $E_{250: 365}$ and $\mathrm{Sr}$ in Nanhu Lake is likely due to the fact that the sewage water has different DOM composition, resulting in different CDOM characteristics compared to other fresh waters.

To analyze the climatic variables' influence on dissolved carbon in waters across the Songnen Plain further, multiple linear regression analyses were performed on both DOC and DIC using precipitation $(P)$, potential evapotranspiration $\left(\mathrm{ET}_{0}\right.$, calculated based on FAO-Penman-Monteith equation), and sunshine duration hours $(S)$ as independent variables. As expected, the $\mathrm{ET}_{0}$ has large impacts on DOC with respect to precipitation and sunshine duration hours (see slope value for $\mathrm{ET}_{0}$ in Table 4). The $\mathrm{ET}_{0}$ representing the water output for the brackish waters results in the condensed effect on DOC concentration. In contrast, an inverse trend was observed between DIC and climatic variables (Table 4). The observation indicates that climatic variables exerted significant impacts on DOC and DIC concentration in the Songnen Plain. So far, our explanation is that sunshine duration may enhance photobleaching that could speed up DOC conversion to DIC (Wetzel, 2001; Lapierre et al., 2012). Further investigation is needed to examine possible underlying reasons.

\subsection{Seasonal variation}

The DOC in waters showed seasonal dynamics due to hydrological, climatic and landscape variation (Jaffé et al., 2008; Spencer et al., 2012). As mentioned above, high DOC concentrations in both the STR and CGL in May are attributed to winter accumulated dissolved carbon in soil flushed into 
stream or lakes during the snowmelt season in cold temperate zones (Ågren et al., 2007; C. C. Song et al., 2011). Similar findings have been reported in streams in Sweden (Ågren et al., 2007, 2010), in water across USA (Jaffé et al., 2008; Helms et al., 2008), and catchments that drain into the Arctic Ocean (Neff et al., 2006; Spencer et al., 2008). The DOC concentration in fresh waters in the ice-free season can be very variable, depending on the hydrological and climatic condition, and landscape in the catchment (Wetzel, 2001; Jaffé et al., 2008; Spencer et al., 2012). However, low DOC is generally expected in fresh waters during low flow season due to limited allochthonous input. Decreased autochthonous origin due to low algal abundance resulting from temperature in the STR could be another reason for the relatively low DOC concentration in October (Fig. 4a). The high DOC concentrations for the CGL in autumn are probably due to the fact that evaporation exceeds inflow and results in condensed DOC concentration. In summer (July, August and September), a large amount of recipient water from precipitation and runoff diluted DOC in the water is the main reason for the low DOC concentration (Fig. 4a).

High molecular weight DOC is more abundant in the early stages of the growing season (May) in the Songnen Plain, and large molecular weight CDOM prevails in the spring with snowmelt as reported by Ågren et al. (2007, 2010). Overall, the STR shows higher SUVA $_{254}$ values than the CGL due to its more terrestrial DOM inputs and less residence time (Hood et al., 2003). Note that overall patterns show large molecular CDOM dominates in fresh waters, and different indices (e.g., the $\mathrm{SUVA}_{254}, E_{250: 365}$ and $\mathrm{Sr}$ ) demonstrate variations for CDOM characterizing in different seasons for both fresh and brackish waters (Fig. 5a-c). The underlying reason is probably due to the seasonal variation and major sources of CDOM concentration (Spencer et al., 2012), particularly after punctuated discharge events coming from different landscapes, which are consistent with investigations by Wilson and Xenopoulos (2008, 2009).

\subsection{Dissolved carbon vs. salinity}

Within semi-humid and semi-arid regions, dissolved carbon is related to salinity, reflecting water residence times and dissolved matter accumulation (Duarte et al., 2008; Mattsson et al., 2009). This relationship implies that the source and sink patterns are similar among lakes within semi-arid regions (Cole et al., 1994; Duarte et al., 2008). The most likely explanation is that the most resilient DOM is evapo-concentrated in the semi-arid region. The relationship of DIC and salinity is more consistent (Fig. $6 \mathrm{~b}$ and d), while the slope and intercept for the DOC and salinity regression model vary (Fig. 6a and c). Comparatively, DIC is more stable, which explains the stable relationship between DIC and salinity (Lapierre and Giorgio, 2012). An empirical model can be calibrated with a comprehensive data set covering waters across the Songnen Plain for estimating DIC storage. However, DOC is more labile (more sensitive to photochemical and microbial degradation) with different source (allochthonous or autochthonous) and composition (Spencer et al., 2009, 2012), resulting in different relationships between DOC and salinity. If a model is calibrated with data sets collected in various seasons, it is also possible to estimate DOC concentration in the Songnen Plain for the variance $\left(R^{2}>0.6\right)$ it could explain.

\subsection{Future implications}

The ability to derive DIC concentration via salinity in the Songnen Plain implies improved carbon storage estimates in the semi-arid region. To quantify the carbon cycling for inland waters, calculation of the flux of dissolved carbon for inland waters is dependent on accurately constraining the concentration and volume of water bodies (Cole et al., 2007; Duarte et al., 2008; Tranvik et al., 2009). Thereby any technique that can improve flux estimates is of assistance in improving fresh and brackish waters delineation and DIC estimates. Recent studies have realized the limitation for quantifying carbon flux of inland brackish waters (Cole et al., 2007; Duarte et al., 2008; Tranvik et al., 2009). The correlation between DIC and salinity from the Songnen Plain strengthens the ability to increase spatiotemporal resolution easily through quick in situ data collection. If such an approach across other watersheds with similar conditions proves to be effective, it will lead to quick estimates of dissolved carbon storage coupled with remote sensing technology (Cole et al., 2007; Tranvik et al., 2009) for providing water surface area, and possible volume (Hendriks et al., 2012). However, this relationship generally varies depending on the source of CDOM and DOC (Spencer et al., 2009, 2012). Coupled with remote sensing, the close relationship between CDOM and DOC provides potential for dissolved carbon storage estimates (Griffin et al., 2011).

\section{Conclusions}

The knowledge of DOC and DIC in brackish inland waters is rare and incomplete. However, it has important implications for carbon cycling in saline (includes brackish) inland waters. A comprehensive study is require for understanding dissolved carbon characteristics that facilitate carbon cycling estimates for inland waters, particularly brackish waters in semi-arid or arid regions. For the first time, the characteristics of DOC and DIC in fresh and brackish waters in the Songnen Plain, China, have been investigated. This study provides insight into carbon cycles linked to hydro-climatic conditions in semi-arid inland waters. The following can be concluded: (1) compared to open waters in the southeast of the Songnen Plain, high DOC and DIC concentrations are observed in the brackish waters in the western part of the plain; (2) terminal aquatic environments result in elevated DOC and DIC concentration, and significant correlations between 
salinity-DOC and salinity-DIC providing a means for predicting dissolved carbon estimates from salinity; (3) relatively high molecular weight DOC fractions are more abundant in fresh waters. The elevated DOC and DIC levels in the semi-arid Songnen Plain might inspire further investigation for understanding the carbon cycling process in brackish aquatic ecosystems, which has not yet been fully done for saline (including brackish) inland waters across the world.

Acknowledgements. This study was financially supported by the National Natural Science Foundation of China (No. 41030743 and No. 41171293). The authors would also like to thank the students, staff and faculty of the Department of Geography Sciences at Harbin Normal University for field campaigns and laboratory analyses. The authors are grateful for all the valuable comments forwarded by the handling editor and two anonymous reviewers that really strengthened our manuscript.

Edited by: M. Hrachowitz

\section{References}

Ågren, A., Buffam, I., Jansson, M., and Laudon, H.: Importance of seasonality and small streams for the landscape regulation of dissolved organic carbon export, J. Geophys. Res., 112, G03003, doi:10.1029/2006JG000381, 2007.

Ågren, A., Haei, M., Köhler, S. J., Bishop, K., and Laudon, H.: Regulation of stream water dissolved organic carbon (DOC) concentrations during snowmelt; the role of discharge, winter climate and memory effects, Biogeosciences, 7, 2901-2913, doi:10.5194/bg-7-2901-2010, 2010.

APHA/AWWA/WEF: Standard methods for the examination of water and wastewater, Washington, DC: American Public Health Association, 1998.

Armstrong, N.: Lake carbon, Nat. Geosci., 3, p. 151, 2010.

Astoreca, R., Rousseau, V., and Lancelot, C.: Colored dissolved organic matter (CDOM) in Southern North Sea waters: Optical characterization and possible origin, Estuar. Coast. Shelf S., 85, 633-640, 2009

Babin, M., Stramski, D., Ferrari, G. M., Claustre, H., Bricaud, A., Obolensky, G., and Hoepffner, N.: Variations in the light absorption coefficients of phytoplankton, nonalgal particles, and dissolved organic matter in coastal waters around Europe, J. Geophys. Res., 108, doi:10.1029/2001JC000882, 2003.

Baker, A. and Spencer, R. G. M.: Characterization of dissolved organic matter from source to sea using fluorescence and absorbance spectroscopy, Sci. Total Environ., 333, 217-232, 2004.

Barros, N., Cole, J. J., Tranvik, L. J., Prairie, Y. T., Bastviken, D., Huszar, V. L., del Giorgio, P., and Roland, F.: Carbon emission from hydroelectric reservoirs linked to reservoir age and latitude, Nat. Geosci., 4, 593-596, 2011.

Binding, C. E., John, H. J., Bukata, R. P, and William, G. B.: Spectral absorption properties of dissolved and particulate matter in Lake Erie, Remote Sens. Environ., 112, 1702-1711, 2008.
Bricaud, A., Babin, M., Morel, A., and Claustre, H.: Variability in the chlorohypll-specific absorption coefficients of natural phytoplankton: Analysis and parameterization, J. Geophys. Res., 100, 13321-13332, 1995.

Brooks, P. D. and Lemon, M. M.: Spatial variability in dissolved organic matter and inorganic nitrogen concentration in a semiarid stream, San Pedro River, Arizona, J. Geophys. Res., 112, G03S05, doi:10.1029/2006JG000262, 2007.

Carlson, R. E.: A trophic state index for lakes, Limnol. Oceanogr. 22, 361-369, 1977.

Chin, Y. P., Aiken, G., and O'Loughlin, E.: Molecular weight, polydispersity, and spectroscopic properties of aquatic humic substances, Environ. Sci. Technol., 26, 1853-1858, 1994.

Cole, J. J., Caraco, N. F., Kling, G. W., and Kratz, T. K.: Carbon dioxide supersaturation in the surface of lakes, Science, 265 , 1568-1570, 1994.

Cole, J. J., Prairie, Y. T., Caraco, N. F., McDowell, W. H., Tranvik, L. J., Striegl, R. G., Duarte, C. M., Kortelainen, P., Downing, J. A., Middelburg, J. J., and Melack, J.: Plumbing the Global Carbon Cycle: Integrating Inland Waters into the Terrestrial Carbon Budget, Ecosystems 10, 171-184, 2007.

Cory, N., Buffam, I., Laudon, H., Kohler, S., and Bishop, K. Landscape control of stream water aluminum in a boreal catchment during spring flood, Environ. Sci. Technol., 40, 3494-3500, 2006.

Curtis, P. J. and Adams, H. E.: Dissolved organic matter quantity and quality from freshwater and saltwater lakes in east-central Alberta, Biogeochemistry, 30, 59-76, 1995.

De Haan, H. and De Boer, T.: Applicability of light absorbance and fluorescence as measures of concentration and molecular size of dissolved organic carbon in humic Laken Tjeukemeer, Water Res., 21, 731-734, 1987.

Downing, J. A., Cole, J. J., Middelburg, J. J., Striegl, R. G., Duarte, C. M., Kortelainen, P., Prairie, Y. T., and Laube, K. A.: Sediment organic carbon burial in agriculturally eutrophic impoundments over the last century, Global Biogeochem. Cy., 22, GB1018, doi:10.1029/2006GB002854, 2008.

Duarte, C. M., Prairie, Y. T., Montes, C., Cole, J. J., Striegl, R. G., Melack, J., and Downing, J. A.: $\mathrm{CO}_{2}$ emission from saline lakes: A global estimates of a surprisingly large flux, J. Geophys. Res., 113, G04041, doi:10.1029/2007JG000637, 2008.

Fichot, C. G. and Benner, R.: A novel method to estimate DOC concentrations from CDOM absorption coefficients in coastal waters, Geophys. Res. Lett., 38, L03610, doi:10.1029/2010GL046152, 2011

Fellman, J. B., Petrone, K. C., and Grierson, F.: Source, biogeochemical cycling, and fluorescence characteristics of dissolved organic matter in an agro-urban estuary, Limnol. Oceanogr., 56, 243-256, 2011.

Granéli, W., Lindell, M., and Tranvik, L.: Photo-oxidative production of dissolved inorganic carbon in lakes of different humic content, Limnol. Oceanogr., 41, 698-707, 1996.

Griffin, C. G., Frey, K. E., Rogan, J., and Holmes, R. M.: Spatial and interannual variability of dissolved organic matter in the Kolyma River, East Siberia, observed using satellite imagery, J. Geophys. Res., 116, G03018, doi:10.1029/2010JG001634, 2011. 
Helms, J. R., Stubbins, A., Ritchie, J. D., Minor, E. C., Kieber, D. J., and Mopper, K.: Absorption spectral slopes and slope ratios as indicators of molecular weight, source, and photobleaching of chromophoric dissolved organic matter, Limnol. Oceanogr., 53, 955-969, 2008.

Hendriks, A. J., Schipper, A. M., Caduff, M., and Huijbregts, M. A. J.: Size relationships of water inflow into lakes: empirical regressions suggest geometric scaling, J. Hydrol., 414-415, 482-490, 2012.

Henneberry, Y. K., Kraus, T. E. C., Fleck, J. A., Krabbenhoft, D. P., Bachand, P. M., and Horwath, W. R.: Removal of inorganic mercury and methylmercury from surface waters following coagulation of dissolved organic matter with metal-based salts, Sci. Total Environ., 409, 631-637, 2011.

Hood, E. W., Mcknight, D. M., and Williams, M. W.: Sources and chemical character of dissolved organic carbon across an alpine/subalpine ecotone, Green Lakes Valley, Colorado Front Range, United States, Water Resour. Res., 39, 1188, doi:10.1029/2002WR001738, 2003.

Jaffé, R., McKnight, D., Maie, N., Cory, R., McDowell, W. H., and Campbell, J. L.: Spatial and temporal variations in DOM composition in ecosystems: The importance of long-term monitoring of optical properties, J. Geophys. Res., 113, G04032, doi:10.1029/2008JG000683, 2008.

Julian, J. P., Doyle, M. W., Powers, S. M., Stanley, E. H., and Riggsbee, J. A.: Optical water quality in rivers, Water Resour. Res., 44, W10411, doi:10.1029/2007WR006457, 2008.

Julian, J. P., Seegert, S. Z., Powers, S. M., Stanley, E. H., and Doyle, M. W.: Light as a first-order control on ecosystem structure in a temperate stream, Ecohydrology, 4, 422-432, 2011.

Lapierre, J. F. and Giorgio, P. A.: Geographical and environmental drivers of regional differences in the lake $p \mathrm{CO}_{2}$ versus DOC relationship across northern landscapes, J. Geophys. Res., 117, G03015, doi:10.1029/2012JG001945, 2012.

Larson, J. H., Frost, P. C., Zheng, Z. Y., Johnston, C. A., Bridgham, S. D., Lodge, D. M., and Lamberti, A. A.: Effects of upstream lakes on dissolved organic matter in streams, Limnol. Oceanogr., 52, 60-69, 2007.

Ledesma, J. L., Köhler, S. J., and Futter, M. N.: Long-term dynamics of dissolved organic carbon: Implications for drinking water supply, Sci. Total Environ., 432, 1-11, 2012.

Mattsson, T., Kortelainen, P., Laubel, A., Evans, D., Pujo-Pay, M., Räike, A., and Conan, P.: Export of dissolved organic matter in relation to land use along a European climatic gradient, Sci. Total Environ., 407, 1967-1976, 2009.

Moore, S., Gauci, V., Evans, C. D., and Page, S. E.: Fluvial organic carbon losses from a Bornean blackwater river, Biogeosciences, 8, 901-909, doi:10.5194/bg-8-901-2011, 2011.

Neff, J. C., Finlay, J. C., Zimov, S. A., Davydov, S. P., Carrasco, J. J., Schuur, E. A. G., and Davydova, A. I.: Seasonal changes in the age and structure of dissolved organic carbon in Siberian rivers and streams, Geophys. Res. Lett., 33, L23401, doi:10.1029/2006GL028222, 2006.

Para, J., Coble, P. G., Charrière, B., Tedetti, M., Fontana, C., and Sempéré, R.: Fluorescence and absorption properties of chromophoric dissolved organic matter (CDOM) in coastal surface waters of the northwestern Mediterranean Sea, influence of the Rhône River, Biogeosciences, 7, 4083-4103, doi:10.5194/bg-74083-2010, 2010.
Peuravouri, J. and Pihlaja, K.: Molecular size distribution and spectroscopic properties of aquatic humic substances, Anal. Chim. Ac., 337, 133-149, 1997.

Philips, F. M.: Soil-water bypass, Nat. Geosci., 3, 77-78, 2010.

Schlesinger, W. H., Cole, J. J., Finzi, A. C., and Holland, E. A.: Introduction to coupled biogeochemical cycles, Front. Ecol. Environ., 9, 5-8, 2011.

Sobek, S., Tranvik, L. J., Prairie, Y. T., Kortelainen, P., and Cole, J. J.: Patterns and regulation of dissolved organic carbon: An analysis of 7,500 widely distributed lakes, Limnol. Oceanogr., 52, 1208-1219, 2007.

Song, C. C., Wang, L. L., Guo, Y. D., Song, Y. Y., Yang, G. S., and Li, Y. C.: Impacts of natural wetland degradation on dissolved carbon dynamics in the Sanjiang Plain, Northeastern China, J. Hydrol., 398, 26-32, 2011.

Song, K. S., Liu, D. W., Li, L., Wang, Z. M., Wang, Y. D., and Jiang, G. J.: Spectral absorption properties of colored dissolved organic matter (CDOM) and total suspended matter (TSM) of inland waters, Proc. SPIE, 7811:78110B, doi:10.1117/12.859634, 2010.

Song, K. S., Wang, Z. M., Blackwell, J., Li, F., Zhang, Y. Z., and Jiang, G. J.: Water quality monitoring using Landsat Thematic Mapper data with empirical algorithms in Chagan Lake, China, J. Appl. Remote Sens., 5, 053506-1-16,doi:10.1117/1.3559497, 2011.

Song, K. S., Li, L., Lenore, L. P., Li, S., Duan, H. T., Liu, D. W., Hall, B. E., Du, J., Li, Z. C., Shi, K., and Zhao, Y.: Remote estimation of chlorophyll-a in turbid inland waters: Three-band model versus GA-PLS model, Remote Sens. Environ., 136, 342 357, 2013.

Spencer, R. G. M., Aiken, G. R., Wickland, K. P., Striegl, R. G., and Hernes, P. J.: Seasonal and spatial variability in dissolved organic matter quantity and composition from the Yukon River basin, Alaska, Global Biogeochem. Cy., 22, GB4002, doi:10.1029/2008GB003231, 2008.

Spencer, R. G. M., Stubbins, A., Hernes, P. J., Baker, A., Mopper, K., Aufdenkampe, A. K., Dyda, R. Y., Mwamba, V. L., Mangangu, A. M., Wabakanghanzi, J. N., and Six, J.: Photochemical degradation of dissolved organic matter and dissolved lignin phenols from the Congo River, J. Geophys. Res., 114, G03010, doi:10.1029/2009JG000968, 2009.

Spencer, R. G. M., Butler, K. D., and Aiken, G. R.: Dissolved organic carbon and chromophoric dissolved organic matter properties of rivers in the USA, J. Geophys. Res., 117, G03001, doi:10.1029/2011JG001928, 2012.

Stedmon, C. A., Thomas, D. N., Papadimitriou, S., Granskog, M. A., and Dieckmann, G. S.: Using fluorescence to characterize dissolved organic matter in Antarctic sea ice brines, J. Geophys. Res., 116, G03027, doi:10.1029/2011JG001716, 2011.

Tobias, C. and Bohlke, J. K.: Biological and geochemical controls on diel dissolved inorganic carbon cycling in a low-order agricultural stream: implications for reach scales and beyond, Chem. Geol., 283, 18-30, 2011.

Tranvik, L. J., Downing, J. A., Cotner, J. B., Loiselle, S. A., Striegl, R. G., Ballatore, T. J., Dillon, P., Finlay, K., Fortino, K., Knoll, L. B., Kortelainen, P. L., Kutser, T., Larson, S., Laurion, I., Leech, D. M., McCallister, S. L., McKnight, D. M., Melack, J. M., Overholt, E., Porter, J. A., Prairie, Y., Renwick, W. H., Roland, F., Sherman, B. S., Schindler, D. W., von Wachenfeldt, E., and Weyhenmeyer, G. A.: Lakes and reservoirs as regulators 
of carbon cycling and climate, Limnol. Oceanogr., 54, 22982314, 2009.

Twardowski, M. S. and Donaghay, P. L.: Photobleaching of aquatic dissolved materials: absorption removal, spectral alteration, and their interrelationship, J. Geophys. Res., 107, 6.1-6.12, 2002.

Twardowski, M. S., Boss, E., Sullivan, J. M., and Donaghay, P. L.: Modeling the spectral shape of absorption by chromophoric dissolved organic matter, Mar. Chem., 89, 69-88, 2004.

Vodacek, A., Blough, N. V., Degrandpre, M. D., Peltzer, E. T., and Nelson, R. K.: Seasonal variation of CDOM and DOC in the Middle Atlantic Bight: terrestrial inputs and photooxidation, Limnol. Oceanogr., 42, 674-686, 1997.

Wang, L., Seki, K., Miyazaki, T., and Isihama, Y.: The causes of soil alkalinization in the Songnen Plain of Northeast China, Paddy Water Environment, 7, 259-270, 2009.

Wang, S. and Dou, H.: Chinese Lake Catalogue. Science Press, Beijing, 1998.

Weishaar, J. L., Aiken, G. R., Bergamaschi, B. A., Fram, M. S., Fugii, R., and Mopper, K.: Evaluation of specific ultraviolet absorbance as an indicator of the chemical composition and reactivity of dissolved organic carbon, Environ. Sci. Technol., 37, 47024708, 2003.

Wetzel, R. G.: Limnology: Lake and River Ecosystems, 3rd Edn., Academic Press, San Diego, 2001.

Williamson, C. E. and Rose, K. C.: When UV meets fresh water, Science, 329, 637-639, 2010.
Wilson, H. and Xenopoulos, M. A.: Ecosystem and seasonal control of stream dissolved organic carbon along a gradient of land use, Ecosystems, 11, 555-568, 2008.

Wilson, H. and Xenopoulos, M. A.: Effects of agricultural land use on the composition of fluvial dissolved organic matter, Nat. Geosci., 2, 37-41, 2009.

Zeng, L. H., Song, K. S., Zhang, B., Li, L., and Wang, Z. M.: Evapotranspiration estimation using moderate resolution imaging spectroradiometer products through a surface energy balance algorithm for land model in Songnen Plain, China, J. Appl. Remote Sens., 5, 053535-1-14, doi:10.1117/1.3609840, 2011.

Zepp, R. G. and Schlotzhauer, P. F.: Comparison of photo-chemical behavior of various humic substances in water. III. Spectroscopic properties of humic substances, Chemosphere, 10, 479486, 1981.

Zhang, Y. L., Qin, B. Q., Zhu, G. W., Zhang, L., and Yang, L. Y.: Chromophoric dissolved organic matter (CDOM) absorption characteristics in relation to fluorescence in Lake Taihu, China, a large shallow subtropical lake, Hydrobiologia, 581, 43-52, 2007.

Zhang, Y. L., Zhang, E. L., Yin, Y., Van Dijk, M. A., Feng, L. Q., Shi, Z. Q., Liu, M. L., and Qin, B. Q.: Characteristics and sources of chromophoric dissolved organic matter in lakes of the Yungui Plateau, China, differing in trophic state and altitude, Limnol. Oceanogr., 55, 2645-2659, 2010. 